\title{
Contextual Learning: Innovative Approach towards the Development of Students' Scientific Attitude and Natural Science Performance
}

\author{
Evi Suryawati ${ }^{1}$, Kamisah Osman ${ }^{2 \star}$ \\ ${ }^{1}$ University of Riau, INDONESIA \\ ${ }^{2}$ National University of Malaysia, MALAYSIA
}

Received 10 June 2017 - Revised 10 August 2017 • Accepted 18 September 2017

\begin{abstract}
This study is specifically designed to measure the effectiveness of Contextual Teaching and Learning (CTL) on the students' scientific attitude and achievement in Natural Science among Junior school students in Pekanbaru, Indonesia. This quasi experiment involved some 215 Form VII students from three public schools, segregated based on their existing cognitive abilities. The CTL materials was developed by applying RANGKA strategy. Overall, the findings revealed that there is significant difference exist across experimental groups in terms of students' achievement. However, there is no significant difference in terms of scientific attitude. These findings contribute significant implications for the enhancement of scientific thinking skills among various students' capabilities and different categories of school. Contextual teaching strategy is found appropriate in achieving the above dimensions in heterogeneous schools. This is due to the fact that the RANGKA contextual learning strategy as developed in this study focuses on the right way for students to learn.
\end{abstract}

Keywords: achievement, contextual learning, Indonesian curriculum, natural science, scientific attitude

\section{INTRODUCTION}

History of the civilization development has witnessed that science knowledge is needed in our everyday life to fulfill humans' needs through the solution of the identified problems. Science knowledge needs to be applied wisely in order to protect and preserve the environmental sustainability. In the context of science curriculum implementation in Indonesia, Depdiknas (2005) hopes that there is an emphasis on integrated learning based on experience learning in the Lower Secondary School in order to create a masterpiece through the application of scientific concepts and competencies. Generally, the Lower Secondary School students are between the aged of 11 to 15 years, thus students at this level of development are at the format operations stage as according to Piaget (1966). Students at this level are capable to perform logical operations wisely though firmly based on a limited learning experience. Besides, they are connected with hypothetical problems and are able to think logically. With respect to the development of Lower Secondary School students, teachers should apply a variety of learning strategies to ensure that the students' cognitive skills are developed effectively.

Analysis of literature has shown that science learning is most effective when students are exposed to inquiry learning methods because in such a learning environment, learning with enthusiasm and in a pleasant atmosphere (Zemelman et al 1998). Students will learn from what they did, and from their experience (Schelecty, 1997). He said science teaching and learning should incorporate a wide range of methods and approaches that provide opportunities for students to perform exploration through relevant activities to enable them to build conceptual understanding in a meaningful way. Strictly speaking, inquiry learning allows students to develop the skills and appearance that indirectly teaches them how to learn something, to train them to always strive to develop reasoning and creativity towards self-development as a whole.

(C) Authors. Terms and conditions of Creative Commons Attribution 4.0 International (CC BY 4.0) apply.

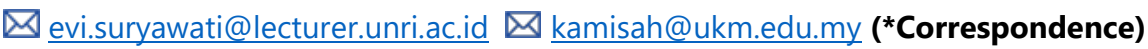




\section{Contribution of this paper to the literature}

- Research has indicated that authentic problem in teaching and learning process can improve students critical and creative thinking.

- Student centered learning will be interesting, challenging, and stimulates social interaction for achievement of learning objectives.

- Contextual learning has a function in improving teacher's role as facilitator to guide students construct their knowledge in order to be smart, creative, and innovative person just like the expectation of the 21st century education.

One of the student-centered approaches that have these characteristics is contextual learning. In the contextual teaching and learning, students are given the opportunity to construct relationship in the context of a more relevant and meaningful to them. Hence, no wonder why contextual learning is often hypothesized as an effective teaching method in improving students' potential and thus make them to be more interested in science learning (Johnson 2002). As an execution, emphasis should be given to the cognitive, affective and psychomotor elements and strengthened with authentic assessment. In the meantime, students also are educated towards the overall development of their character.

In Indonesia, natural science subject is one of the subjects in Lower Secondary Schools that are clustered with Physics and Chemistry in Science. Form 1 science learning in Lower grade VII Secondary School consists of seven basic competencies namely: (1) Understanding the scientific procedure to study natural objects using appropriate equipments, (2) Understanding the classification of substances, (3) Understanding the existence of substance and its change, (4) Understanding the various nature of physical and chemical changes, (5) Understanding of natural phenomena through observation, (6) Understanding the diversity of living things, and (7) Understanding the interdependence of the ecosystem (Depdiknas, 2013).

In general, the purpose of natural science teaching is to enable students to master the basic principles of biology, as well as organizing the scientific method that is based on scientific attitude to solve problems in natural science and to realize the majesty and greatness of Allah.

According to Rustaman (2008), scientific process is not just limited to data gathering, but it also sharpens the mental processes and manipulative skills. Accordingly, the objective of this subject also includes the means to understand the nature of nature. Science is not only conceptualized as a product, but a process of knowledge acquisition about natural phenomena.

Carin (1993) suggested that there are four key aspects that should be taken into serious attention in science learning which are the content, science process, creative thinking and attitude cultivation. Main and Rowe (1993) also stressed that science learning should be emphasizing on problem-solving process. This will in turn lead to improvement on the students' thinking skills i.e. making inference, analyzing, synthesizing and evaluating skills rather. Despite the proof in fostering students' interest to learn science while instilling positive scientific attitude and increasing students' achievement, on average there are still many science learning activities practice that lead to the transfer of facts without trying to adopt the inquiry method and other approaches that engage students actively in learning (Chiapetta \& Koballa, 2002).

The importance of scientific attitude was also emphasized by Kamisah et al. (2007) stating that the scientific attitude is a necessary precondition and behavior to be practiced by any science community. This attitude is built by inclination, adaptability, appreciation and expected values as highlighted by scientists in performing their job. This is consistent with what is presented by Anderson and Krathwohl (2001), where the results of learning should cover on the cognitive, affective and psychomotor domain, thus it is expected after going through a learning process students are able to master all the domains.

Science emphasizes inquiry and problem-solving method. In the process of inquiry and problem solving, scientific and thinking skills are used. Scientific skills are important in any scientific investigation. Scientific methods such as experiments, research and projects are activities that use scientific skills. In solving the problems that occurred in the surroundings, students can discuss, help each other and share experiences with the learning community thus giving rise to curiosity. Curiosity in turn will increase students' interest in learning so students are more motivated to learn enthusiastically. According to Pintrich and Schunk (1996), exposure to authentic problem can motivate students and improve their achievement. Harlen (1996) also stressed that science literacy is owned by a person with the ability to analyze a phenomenon scientifically and foresee whether it is happening based on evidence or otherwise. To achieve this level of scientific literacy, one must not only have a positive attitude towards science, but must equip themselves with the skill and culture with the values of science in every dimension of life.

Critical thinking skills in science are crucial because it can produce a scientific attitude. Scientific attitude according to AAAS (1993) are: a) honesty, b) curiosity, c) open-minded, and d) doubt. While Harlen (1996) 
conceptualized scientific attitude as: a) curiosity, b) respect for data, c) diligent, d) creativity and discovery, e) cooperation, $\mathrm{f}$ ) open minded, g) appreciate others opinion, $\mathrm{h}$ ) are sensitive to the environment. In the context of the implementation of the science curriculum in Indonesia, scientific attitudes include: a) curiosity, b), precision, and accuracy, c) collaboration, d) discipline, e) objectivity, f) humble, g) tolerance, and h) skeptics (Depdiknas, 2005). Wolfensberger, Piniel, Canella, and Kyburz-Graber (2010) further emphasized that such contextual learning activities not only benefit students, but also help the teachers to make reflections on their instructional design. Many educators have pointed out the importance of situating students in authentic contexts and encouraging them to perceive problems, actively collect data, and develop the way to solve problems. Moreover, extending the scope of learning from the classroom to the wider society makes learning more meaningful and helpful to the students (Chu, 2014).

\section{Contextual Teaching Role in the Scientific Attitude Development}

Contextual approach is the cornerstone philosophy of constructivism, namely learning philosophy that emphasizes learning is not just about memorizing. Martin et al. (2002) stated that learning through constructivism will improve students' critical thinking skills and problem solving. Instead, they will also able to use scientific understanding to solve various problems, and continuously will absorb and cultivate the information obtained. Contextual teaching according to Hull and Greveelk (1998) has five characteristics, namely relating, experience, application, collaboration, and displacement. Precisely, it can be formulated that contextual teaching and learning emphasize the importance of students developing the knowledge and experience to think through discovery and problem-solving activities (Parnel, 2001).

Constructivism emphasizes the construction of knowledge based on the interaction of existing knowledge and new knowledge through experience (Von Glasserfeld 1992). According to Vygotsky (1978), students construct their own knowledge through their own experience and the through learning process which students required the assistance from their peers and adults in the form of scaffolding. Muhfahroyin (2009) stated that acculturation on students' critical thinking skills can be achieved through constructivism. In the other hand, Triyanto (2010) states that contextual teaching and learning emphasis on higher order thinking, interdisciplinary knowledge transfer, as well as the collection, analysis and synthesis of information from multiple sources.

The constructivists argue about the learning environment in the context of the rich environment. Knowledge and skills that are robust and meaningful-use can be constructed through related to real life assignments (Hung \& Wong, 2000; Marzano, 1992). Here, project work can be seen as a form of contextual open-ended activity-based learning, and is part of the process of teaching and learning that emphasize problem solving as a collaborative effort (Richmond \& Striley, 1996). Teaching activities are carried out in certain specific expectations (Hung \& Wong 2000). Blumenfeld et al. (1991) state that project based learning model focus on problems and meaningful learning units by blending concepts from different knowledge.

Cognitive development theory founded by Piaget (1966) also describes how a student's learning based on knowledge and cognitive development. Knowledge is not acquired passively, but actively constructed by cognitive structures through practice. Slavin (1991) states Piaget's theory of cognitive development implies that the process of thinking is not only focus on outcomes alone. But more on the process used by students to obtain answers to the questions asked by teachers.

Bruner (1977) states through discovery learning, students will be supported to learn through active involvement to understand the concepts and principles. Moreover, Carin and Bass (2001) states that teaching is considered to be an inquiring approach that can produce scientific skills if teachers are to undertake activities that will guide students toward discovery. The inquiry approach emphasizes learning through student-centered experience. Students will be given the opportunity to investigate a phenomenon using the concept and related knowledge to reach a conclusion.

Inquiry strategy is a learning strategy that builds on constructivist learning, where students develop their own knowledge through problem-solving activities to enhance their understanding, developing skills and scientific literacy (Oates 2002). Kenyon (2003) noted that inquiry-based science learning is an approach that can be used by teachers in science learning that emphasizes on improving students' achievement through developing new knowledge from their surrounding.

According to Beyer (1988), metacognitive skill affects thinking skills and students' achievement. The performance of low achievement students can be enhanced by teaching them cognitive skills. Deshler and Schumaker (1994), suggest that low academic achievement can be overcome by implementing the right teaching and learning strategies.

Science teaching effectiveness can be improved by following systematic procedures. Two important features in a systematic teaching are teaching and learning methods used, and the ongoing collection of information to determine the extent of planning made feasible and yielded the desired results. Therefore, the main task for science 
teachers is to use teaching strategies that enable effective science learning to happen in classroom. Oliva (2004) emphasized the importance of learning strategies selection in attracting students to a subject. According to Vygotsky (1978), activities and tasks that have relevance with the social context of everyday life should be a medium for learning. Teaching strategies that do not have connection with everyday life phenomena will encourage students to perceive that learning in school as something that is separate from their everyday life experiences.

Contextual learning can encourage students to have a more positive attitude in learning science. When students can relate the concepts, they have learned to real-life situations, it means that they have inserted the context learned to the actual situation and transformed it as life experiences (Harwell 1999). Hunkins and Shapiro (1967) suggest the need for appropriate teaching materials to stimulate critical thinking. Furthermore, Daniels and Bizar (1998) emphasize deep learning will enable students to develop an understanding of their world.

Based on the current scenario of science education, the researchers found it is necessary to review the implementation of contextual learning as entrusted by the Indonesian government and enshrined in science education curriculum as a whole. RANGKA contextual learning strategies built in this study is based on the REACT strategy (Crawford 2001). The contextual learning strategy is a student-centered learning strategy that emphasis on the development of higher order thinking and the way they must learn. The objective of this study is to investigate the effect of contextual learning strategies blended with process skills and problem-solving skills on scientific attitude and students' achievement in Natural Science grade VII for Secondary Schools in Kota Pekanbaru, Riau Indonesia. Contextual strategy used is called RANGKA. RANGKA contextual learning is the acronym of $\mathrm{R}=$ rumuskan masalah (problem summary), $\mathrm{A}=$ amati melalui kegiatan (observed through activities), $\mathrm{N}=$ nyatakan (state), $\mathrm{G}=$ gabungkan (merge), $\mathrm{K}=$ kerjasama dan komunikasi (collaboration and communicate), and $\mathrm{A}=$ amalkan (practice). This strategy is built on the basic principles of contextual learning which are science constructivism, inquiry, learning community, modeling, reflection, and authentic assessment. This strategy can be one of the alternative innovations in science learning, and motivation for teachers to always improve the quality of teaching. The problem summary phase, merge and practice phase will establish a better scientific attitude in particular, curiosity, responsibility and cooperation.

\section{RESEARCH METHODOLOGY}

\section{Research Design and Sample}

The research design was quasi-experimental post-test (Creswell 2002, Gall et al 2005) with a 2x3 factorial design. There are two independent variables and four dependent variables. Independent variables involve are teaching strategy (contextual and conventional) and students' ability (high, medium, and low), while the dependent variables involve are scientific attitude, and achievement. In the field of education research, not all variables can be manipulated entirely, thus the selection of quasi-experimental designs for this research is conducted as the classroom and lessons schedule are not flexible to suit the researcher's suitability. The research sample profiles are summarized as Table 1.

Table 1. The Research Sample Profile

\begin{tabular}{ccccc}
\hline No. & School & \multicolumn{2}{c}{ Sample in Group } & School Accreditation/ Sample \\
\hline \multicolumn{1}{c}{} & & Experiment & Control & \\
\hline 2. & SMPN A & 36 & 35 & $\mathrm{~A} / 71$ \\
\hline 3. & SMPN B & 35 & 35 & $\mathrm{~B} / 70$ \\
\hline & SMPN C & 40 & 35 & $\mathrm{~B} / 75$ \\
\hline
\end{tabular}

\section{Module Development}

This research consists of two phases. Phase 1: module construction, and Phase 2: module testing. Contextual teaching and learning is conceptualized as a teaching method, thus the contextual modules in this study perspective is as defined by Rowntree (1990), in which it is a teaching resource materials to help teachers guide students undergo learning. Various models have been put forward in the construction of teaching modules. These include Four D Models (Thiagarajan et al., 1974), Model Kemp et al. (1994), Dick and Carey Model (2005) and ADDIE Models (Gagne et al., 2005). Although there is variation in the procedure or approach used in the module construction, the ultimate goal of all approaches is to produce high quality modules. In order to investigate the effectiveness of the contextual teaching and learning, a contextual module is built on biology topic Living Diversity for semester 2 Primary School VII class. Three modules developed are as follow: 1) Characteristics of living things, 2) Classification of living things, and 3) Diversity of the living things. 


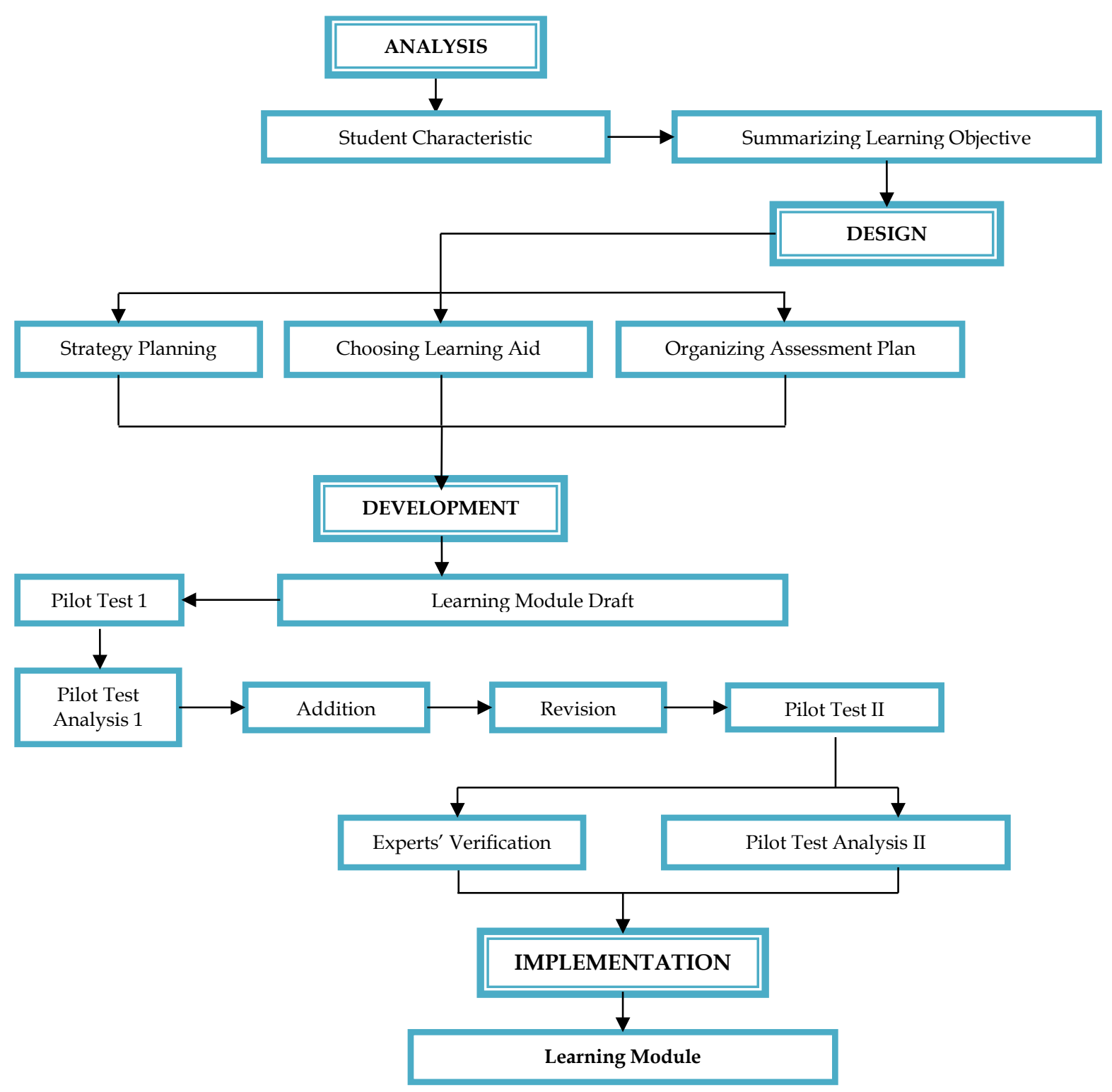

Figure 1. Teaching Module Development

Contextual teaching and learning modules in this study were developed by the researcher by blending the process and problem-solving skills. The contextual strategy used is called RANGKA, by which it is the acronym of $\mathrm{R}=$ Rumuskan masalah (summarize the problem), $\mathrm{A}=$ Amati melalui kegiatan (observed through activities), $\mathrm{N}=$ Nyatakan (state), G = Gabungkan (merge), K= Kerjasama dan Komunikasi (collaboration and communicate), and A = Amalkan (practice). The effectiveness of RANGKA contextual strategies will be observed on the aspects of scientific attitude and students' achievement. This module was developed by referring to Depdiknas (2008) who suggested that any learning modules must be designed by complying standards requirements as stipulated by the National Education Agency.

\section{Research Instrument}

\section{Achievement test}

Face validity and content validity assessment of the module has been performed by four science teaching and learning strategy specialists from the Faculty of Mathematics, Faculty of Natural Sciences and an experienced natural science teacher. The module consisted of lesson plans, books, and student worksheets. Stages in the construction of contextual learning module consist of Working Plans, Teaching Preparation and Teaching Modules. The contextual teaching and learning module lesson plan was modified based on model proposed by Gagne et. al (2005) which composed of Analyze, Design, Develop, Implement, Evaluate (ADDIE Model). 
Natural Science achievement instruments were built by researcher according to research topics that were taught, namely: the characteristics of living things, classification of living things, and the diversity of living things. The questions were in the form of multiple choices, structure and essay. Types of questions compiled were based on Bloom's Taxonomy of cognitive aspects, which comprises of medium level questions (knowledge, comprehension) and higher-level questions (application, analysis). During test item construction process, Test Item Specification Table was developed, which summarize the biology concepts across cognitive domains. Furthermore, items were built based on the constructs assessed in accordance with the policies and indicators of learning competencies. Specification of the biology concept achievement objective test is as presented in Table 2.

Table 2. Natural Science Concept Achievement Test Item Specification for Diversity of Living Things Topic

\begin{tabular}{lcccc}
\hline Conceptual Item & $\begin{array}{c}\text { Knowledge } \\
\text { Objective }\end{array}$ & $\begin{array}{c}\text { Understanding } \\
\text { Objective }\end{array}$ & $\begin{array}{c}\text { Application } \\
\text { Objective }\end{array}$ & $\begin{array}{c}\text { Analysis } \\
\text { Objective }\end{array}$ \\
\hline Living Things Characteristic Identification & 1 & 5 & 4 & - \\
\hline Living Things Classification & 7 & 5 & 5 & 3 \\
\hline Living Organization & 6 & 11 & 2 & 1 \\
\hline Total & 14 & 21 & 11 & 4 \\
\hline
\end{tabular}

To ensure that the items in the objective part of the questionnaire were designed base on knowledge, understanding and application constructs, two groups of evaluators were formed to verify the aspect fulfillment. The first evaluator was a biology teacher with an extensive experience in measurement and evaluation, as well as members of the construction of national final examination questions (national test). On the other hand, the second evaluator was an evaluation and measurement lecturer. At the first stage, the panels were provided with a printout questions and were asked to review and provide feedbacks whether the items were constructed accordingly. Next, both evaluators were asked to match the items base on the appropriate constructs. Items found to correspond to the constructs were considered by the researcher as items for the final biology concept testing. In the third stage, a biology education specialist and a biology lecturer were asked to assess whether the questions were constructed appropriately. Finally, in the fourth stage, three biology teachers with more than 10 years teaching experience involved in assessing the item validity based on three aspects: i) clarity of questions and answers, ii) question appropriateness based on students' ability level, and iii) questions adherence to the syllabus content.

Through Split Half method, a score of 0.69 reliability index was recorded for the biology test instrument. Furthermore, the difficulty index was scored between a range of 0.31 to 0.93 , and discrimination index between 0.44 and 0.76 . The difficulty index and the discrimination index scored were at an acceptable value (Nitko, 2004).

\section{Scientific attitude questionnaire}

Questionnaire was the main instrument used to measure students' scientific attitudes in science learning. According to Anderson (1980), there are two ways that can be used to measure the attitude, which are by observation and also self-report. In the prospective of this study, seven scientific attitudes constructs were covered namely: responsibility, curiosity, teamwork, diligence, discipline, tolerance and confidence. The response to each item was based on a 4 point Likert scale ranging from strongly agree, agree, disagree, and strongly disagree with points given on each scale 4,3,2, and 1 for positive statements, and 1,2,3,4 for negative declaration. Questionnaire content are as shown in Table 3.

Table 3. Students' Scientific Attitude Questionnaire Content

\begin{tabular}{cccc}
\hline Questionnaire & Measured Aspects & No. Of Items & Items No. \\
\hline 1. Responsibility & 3 & $1-3$ \\
\hline 2. Curiousity & 3 & $4-6$ \\
\hline 3. Teamwork & 3 & $7-9$ \\
\hline 4. Dilligence & 3 & $10-12$ \\
\hline 5. Discipline & 3 & $13-15$ \\
\hline 6. Tolerance & 3 & $16-18$ \\
\hline 7. Confidence & 3 & $19-21$
\end{tabular}

Validity is the ability of an instrument to measure what should be measured, while reliability is the consistency of an instrument to measure what should be measured. Reliability is an important feature in determining the research validity (Tuckman 1999). Construct validity and content validity of the questionnaire was determined 
during the instrument development by referring to the research question and experts' review on sentence structure, language, suitability on students' ability level and construct-item fitness. Besides, criterion validity was done by researcher during data analysis. Furthermore, pilot study was done prior to reliability analysis, and a range score of 0.64 to 0.78 Cronbach alpha indexes was obtained. As referred to Pallant (2001), Cronbach alpha value which is above 0.70 is indicated as a reliable instrument.

\section{Data Analysis Procedure}

Data analysis used in this study consisted of descriptive and inferential statistical analysis. Descriptive statistical analysis is composed of frequency, percentage, mean, median, mode, standard deviation of the distribution of scores for each group, while inferential statistic is composed of t-test, Analysis of Variance (ANOVA) and Multivariate Analysis of Variance (MANOVA). ANOVA analysis was executed to find out whether there are significant differences between contextual and conventional groups within students with different ability (high, medium, and low). In other hand, MANOVA was conducted to find out whether there are significant interaction effects between the contextual and conventional with high, low, and moderate students' ability in seven scientific attitude subscale $(2 \times 3 \times 7$ factorial) and 3 subscale achievement test with $2 \times 3 \times 3$ factorial design.

\section{RESEARCH RESULT}

\section{The Effects of Contextual Learning towards Scientific Attitude}

Scientific attitude in this study consist of seven aspects which are responsibility, curiosity, teamwork, diligence, discipline, tolerance, and self-confidence. Effects of RANGKA contextual teaching and learning towards students' scientific attitudes are shown in Tables 4 and 5.

Table 4. Scientific Attitude Mean Score based on Student's Ability Level and Type of Treatment

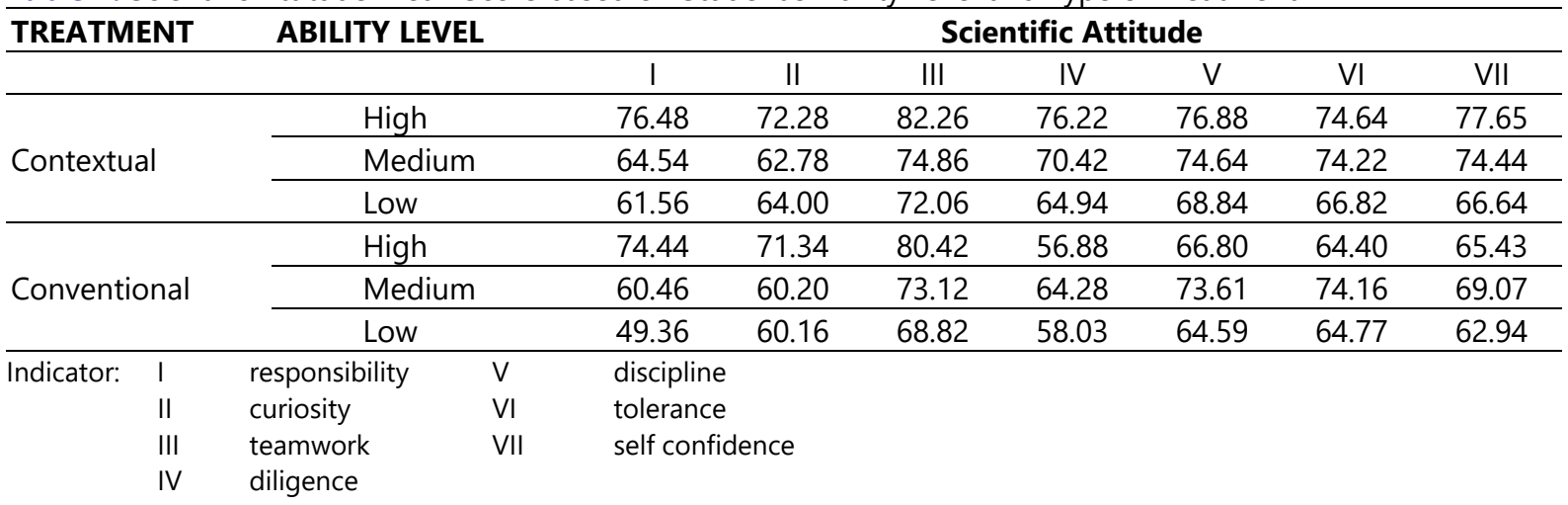

Descriptive findings showed that the highest scientific attitude mean score was recorded on teamwork subscale (mean $=82.26$ ), while the lowest mean score was recorded on responsibility subscale (mean $=49.36)$. These findings indicated that students are able to work as a team, but the responsibility ability among them is still at a low level. Furthermore, in order to answer the formulated research questions and hypotheses, inferential statistical analysis was done. Via independent sample t-test, it can be concluded that there was no significant difference on students' scientific attitude between the contextual strategy treatment group and conventional strategy treatment group. The analysis as in Table 5 .

Table 5. Independent t-test Analysis on Scientific Attitude between Conventional and Contextual Learning Group

\begin{tabular}{lcccccc}
\hline & Treatment & Mean & $\begin{array}{c}\text { Standard } \\
\text { Deviation }\end{array}$ & $\begin{array}{c}\text { Mean Standard } \\
\text { Error }\end{array}$ & t & $\begin{array}{c}\text { Sig. } \\
\text { (2-tailed) }\end{array}$ \\
\hline Scientific & Contextual & 67.829 & 9.1698 & .8949 & 023 & .981 \\
\cline { 2 - 7 } Attitude & Conventional & 67.800 & 8.8450 & .8433 & & \\
\hline
\end{tabular}

Summary results of the ANOVA and post hoc tests are as shown in Table 6 and 7. Besides, the interaction of scientific attitude and the research treatment are as shown in Figure 2. 
Table 6. ANOVA on Scientific Attitude Post-Test Base on Different Student Ability Group in Contextual Teaching Strategy

\begin{tabular}{lcccccc}
\hline & & Sum of Square & df & Mean of Square & F & Sig. \\
\hline \multirow{3}{*}{ Scientific Attitude } & Between Group & 1944.614 & 2 & 972.307 & 14.375 & .000 \\
\cline { 2 - 7 } & Within Group & 7237.240 & 107 & 67.638 & & \\
\cline { 2 - 8 } & Total & 9181.855 & 109 & & & \\
\hline
\end{tabular}

Table 7. Post hoc Bonferroni Result on Students' Scientific Attitude Based on Contextual Learning

\begin{tabular}{|c|c|c|c|c|c|}
\hline $\begin{array}{l}\text { Dependent } \\
\text { Variable } \\
\end{array}$ & (I) Ability & (J) Ability & $\begin{array}{c}\text { Mean difference } \\
(I-J)\end{array}$ & $\begin{array}{c}\text { Standard } \\
\text { error }\end{array}$ & Sig. \\
\hline \multirow{6}{*}{ Scientific Attitude } & High & Medium & $9.7475\left(^{*}\right)$ & 1.78495 & .000 \\
\hline & & Low & $8.9686\left(^{*}\right)$ & 1.92760 & .000 \\
\hline & Medium & High & $-9.7475\left(^{*}\right)$ & 1.78495 & .000 \\
\hline & & Low & -.7789 & 1.84886 & 1.000 \\
\hline & Low & High & $-8.9686\left(^{*}\right)$ & 1.92760 & .000 \\
\hline & & Medium & .7789 & 1.84886 & 1.000 \\
\hline
\end{tabular}

$\left(^{\star}\right)$ significant at level of 0.05

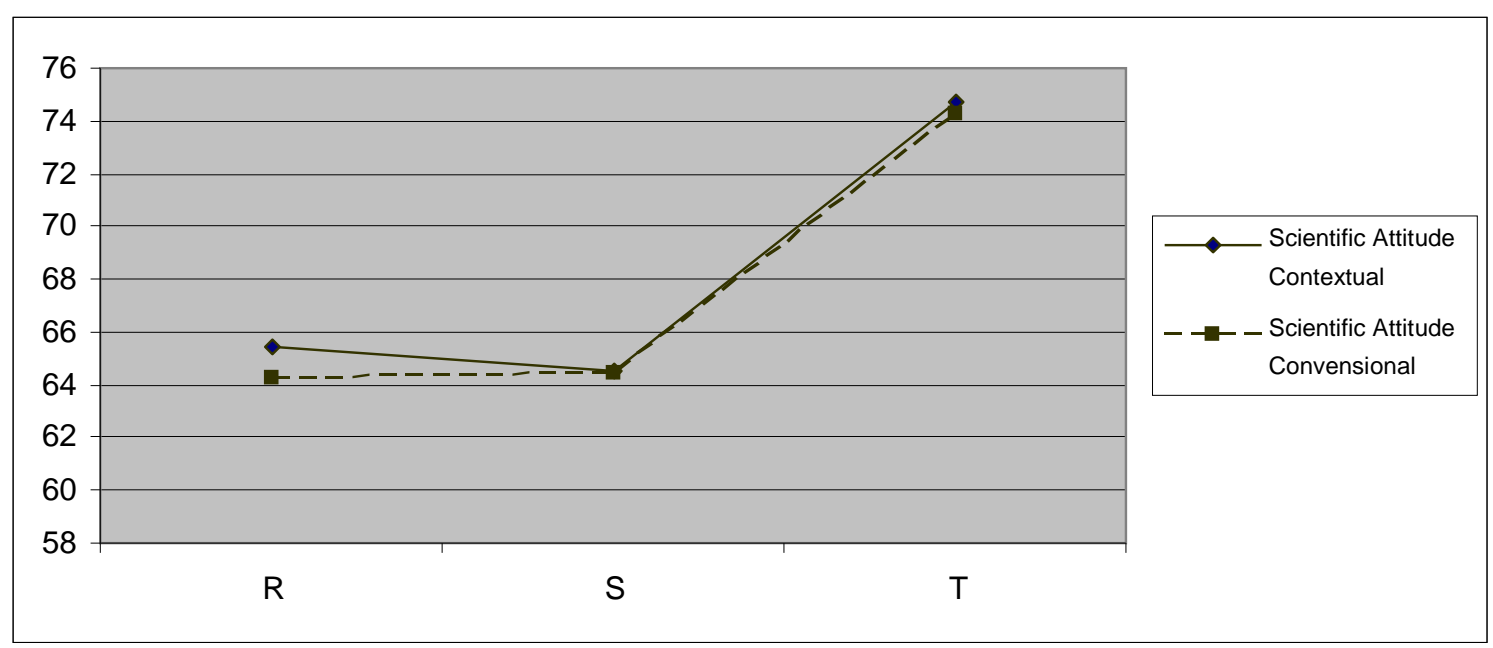

Figure 2. The Interaction of Scientific Attitude and the Research Treatment

From this research, it can be deducted that RANGKA contextual strategy is essential in developing scientific attitude especially in the aspects of curiosity, responsibility and teamwork. Teachers need to be creatively able in using teaching aids and providing authentic and challenging tasks for the students in order to increase their attention in class and directly increasing their scientific attitude. Pedrotti (1997) also stress on sharing and communication element in class session in order to embed teamwork skill among the students.

Furthermore, in an effort to increase students' interest and motivation, students' books and worksheet need to be equipped with suitable colored illustrations. As for example, the illustrations in the modules were taken from the environment according to the activities that are conducted. This is one of the ways to attract students' interest and curiosity. As an impact, students' conceptual understanding will be gradually improved as they are interested in what they are learning.

In overall view, students' scientific attitude on responsibility aspect scored the lowest in the contextual teaching (mean $=61.56)$, and conventional teaching in low ability level students (mean $=61.56)$. This scenario might be due to low level of cognitive maturity and self confidence among them. Lack of responsibility skill were detected through qualitative observation, where the students were less concerned in the instruments condition as well as the overall cleanliness after every lab activity. As noted by Shayer and Adey (1981), most of the high school students have not obtained a formal reasoning in accordance with their age. In fact, for many, they are still at the level of concrete reasoning and most of them continue to be at the stage until the age of 16 years and above. Therefore, it could be argued that low cognitive maturity among most students were the major trigger of low scientific attitudes in particular, on the aspect of responsibility, curiosity, and meticulous. 
On curiosity aspect, low ability students in contextual strategy groups have a higher score $($ mean $=64.00)$ than medium ability contextual strategy group (mean $=62.78$ ). This finding suggested that to develop students' scientific attitude, teachers need to play a big role to implement teaching strategies that can enhance students' self-concept. Teachers need to be more attentive and concerned to students' difficulty in completing their assignments. As a result, students will be more curious and meticulous, and indirectly will increase the students' interests and attitude in science. Philips (1996) found that contextual learning and teaching strategy can inculculate the elements of rationale, open-minded, always looking for an alternative and sensitive to the feelings of others. Moreover, as argued by Bricheno et al. (2000), scientific attitude and a positive attitude toward science is embedded as a result of direct experience with teaching and learning, especially in activities involving students' active involvement.

In line with the study conducted by Chiappetta and Koballa (2002), 72\% of male students and $64 \%$ of female students demonstrate an increment in their interest in laboratory activities with contextual teaching and learning strategy. Furthermore, Blank and Harwell (2001) states that while the students work in the lab, at home or in a group, they will learn from each other, develop an understanding and tolerance, and at the same time, they will also learn to appreciate the value of togetherness.

It should be noted that intellectual achievement is not the sole goal in the implementation of the RANGKA contextual strategy. It also aimed in the development of all education dimensions including personality, emotional, social, and scientific attitude development.

\section{Interaction Effect of Contextual Learning Method towards Students' Achievement}

Figure 3 show concept mastery post-test score between students in the contextual strategy treatment group and conventional strategy treatment group. In addition, inferential analysis was done to test the differences in the concept mastery post-test score between contextual strategy and conventional strategy treatment group. The related result is shown in Table 8. Besides, ANOVA was conducted to investigate whether there are significant differences in the concept mastery post-test scores between the high, medium and low ability students in the contextual teaching strategy group. The summary results of the ANOVA and post hoc Bonferroni test is shown in Tables 9 and 10.

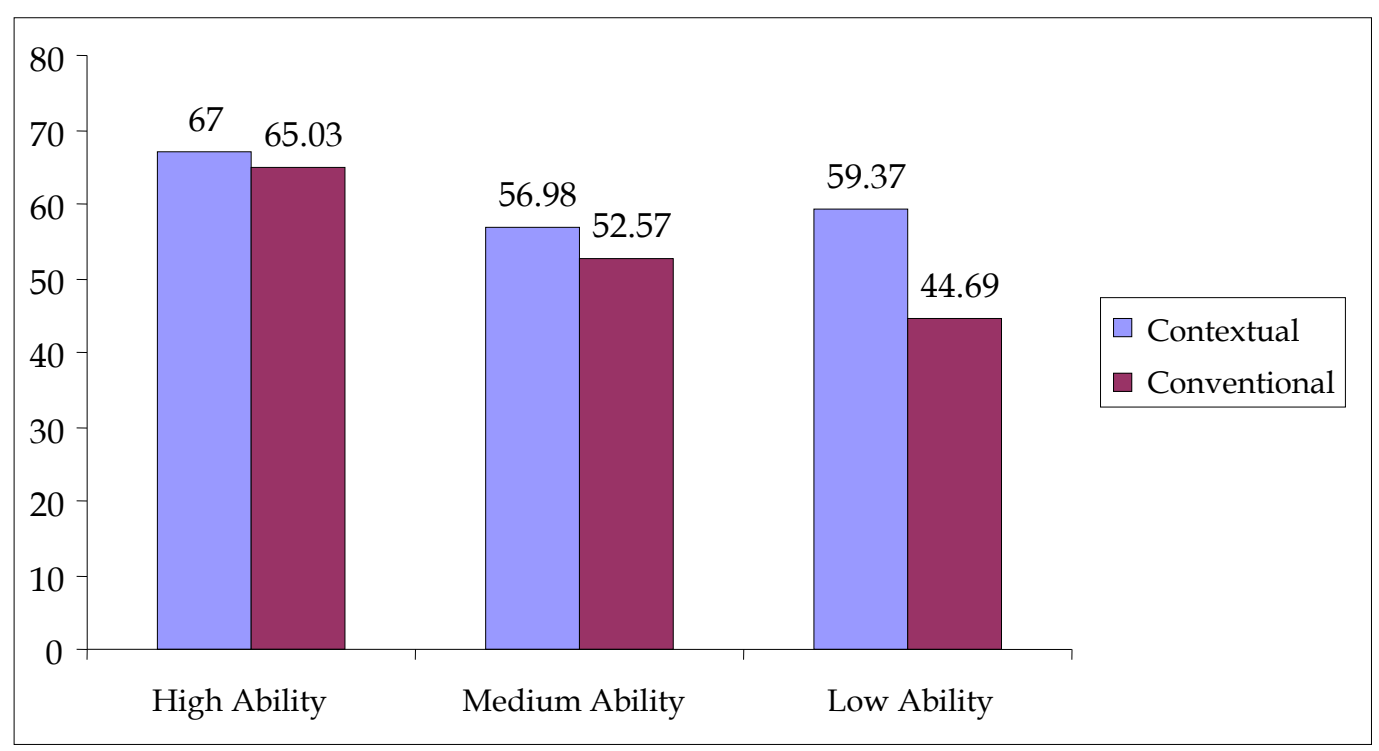

Figure 3. Post-test Scores of Concept Mastery Bar Chart

Table 8. t-test on Concept Mastery Post-Test Scores

\begin{tabular}{lcccccc}
\hline Subject & Treatment & Mean & $\begin{array}{c}\text { Standard } \\
\text { Deviation }\end{array}$ & $\begin{array}{c}\text { Standard Mean } \\
\text { Error }\end{array}$ & t & $\begin{array}{c}\text { Sig. } \\
\text { (2-tailed) }\end{array}$ \\
\hline \multirow{2}{*}{ Post-test } & Contextual & 60.840 & 11.399 & 1.087 & 4.122 & .000 \\
\cline { 2 - 7 } & Conventional & 54.100 & 12.574 & 1.227 & & \\
\hline
\end{tabular}


Table 9. ANOVA on Concept Mastery Post-Test Score of Contextual Learning

\begin{tabular}{|c|c|c|c|c|c|c|}
\hline & & Sum of Square & df & Mean Square & $\mathbf{F}$ & Sig. \\
\hline \multirow{3}{*}{ Objective Post-test } & Between Group & 2323.767 & 2 & 1161.883 & 61.154 & $.000^{*}$ \\
\hline & Within Group & 2032.924 & 107 & 18.999 & & \\
\hline & Total & 4356.691 & 109 & & & \\
\hline \multirow{3}{*}{ Structure Post-test } & Between Group & 828.893 & 2 & 414.447 & 19.895 & $.000^{*}$ \\
\hline & Within Group & 2228.961 & 107 & 20.831 & & \\
\hline & Total & 3057.855 & 109 & & & \\
\hline \multirow{3}{*}{ Essay Post-test } & Between Group & 2437.017 & 2 & 1218.508 & 308.048 & $.000^{*}$ \\
\hline & Within Group & 423.247 & 107 & 3.956 & & \\
\hline & Total & 2860.264 & 109 & & & \\
\hline \multirow{3}{*}{ Overall Post-test } & Between Group & 1977.908 & 2 & 988.954 & 8.684 & $.000^{*}$ \\
\hline & Within Group & 12185.147 & 107 & 113.880 & & \\
\hline & Total & 14163.055 & 109 & & & \\
\hline
\end{tabular}

* significant at $\alpha=0.05$

Table 10. Post-hoc Benferroni Test Result on Concept Mastery Post-Test

\begin{tabular}{|c|c|c|c|c|c|}
\hline Dependent variables & (I) Ability & (J) Ability & $\begin{array}{c}\text { Mean } \\
\text { Difference (I-J) } \\
\end{array}$ & $\begin{array}{c}\text { Standar } \\
\text { Error }\end{array}$ & Sig. \\
\hline \multirow{6}{*}{ Post test } & High & Medium & $11.05\left(^{*}\right)$ & 1.368 & .000 \\
\hline & & Low & $13.97\left(^{*}\right)$ & 1.395 & .000 \\
\hline & Medium & High & $-11.05\left(^{*}\right)$ & 1.368 & .000 \\
\hline & & Low & 2.92 & 1.362 & .330 \\
\hline & Low & High & $-13.97\left(^{*}\right)$ & 1.395 & .000 \\
\hline & & Medium & -2.92 & 1.362 & .330 \\
\hline
\end{tabular}

Students' achievement via contextual learning strategy were seen to increase significantly due to the interaction between the new concepts and prior concepts that had been available in the students' cognitive structure. Besides, the increment is caused due to the application of various teaching aids such as diagrams, graphs and concept maps that are appropriate to the topics learned. As an example, concept maps were used in this study, particularly on the topic of life organization. In the association process between new concept and prior concept, the students will be dragged to conclude that there are gaps between both concepts. As a result, they will find solutions in order to integrate the whole concepts, and this of course requires a high understanding and skills as well as teamwork.

In overall, result from the post-test at the high ability students in the contextual strategy group have higher mean scores $($ mean $=67.00)$ as compared to the medium ability students (mean $=56.98)$ and low $($ mean $=59.97)$. Furthermore, increment in the mean pre-post test scores has been detected on the high ability students (19.29), medium ability (19.91), and low ability students (22.94). This finding showed that RANGKA contextual strategy is more effective on application towards low ability students as compared to medium ability and high ability students. Vygotsky (1978) stated that cognitive development occurs when students interact with adults or individuals with higher capability than they are. This is in aligned with Bruner's (1977) scaffolding strategy.

Quantitatively, medium ability and low ability students' concept mastery achievement have not yet achieved $100 \%$ of the objectives set by the government. According to the Depdiknas (2005), students are said to achieve mastery when they succeed in scoring more than 75. However in overall, the RANGKA contextual strategy conducted was found to produce a significant impact on students' concept achievement. This is in parallel with the suggestion of Deshler and Schumaker (1994) on which achievement of low-ability students can be increased by strategic and systematic teaching procedures.

\section{DISCUSSION}

Distinct teaching planning in contextual modules allows students to provide oral and written responses. Conceptual mastery, critical thinking and good understanding could generate students' motivation to perform scientific evidence written in the form of a paper project. Here are some of the students' responses when completing the worksheet: 
Student 1 (KT): I chose to plant green beans and look at it for 2 weeks so that I know on what day do the beans germinates. Until I can tell my mother how many days do it takes to plant sprouts at home.

Student 2 (KS): My mother had been gathering pictures of my little sister and I, then arranged in a photo album, but the pictures do not contain information about the date and events. Due to it, I will gather all of my pictures from birth until now, and I will give complete details to each of the pictures appropriate with my development.

Student 3 (KR): I have two brothers aged 1 year and 5 years. So, I choose to explain their growth using the available data on 'Kartu Menuju Sihat' (KMS). KMS contain data regarding height and weight development up to the age of 5 years.

Student 4 (KT): I chose to make a herbarium of various types of plants. I would give complete and clear descriptions to all of the plants and I will place it in the school laboratory. Hopefully that will be usefull for those who want to learn.

Student 5 (KS): I'm very happy when I am in city park because there are many butterflies and insects that fly from one flower to another. But I'm also sad because my mother's plants at home are often attacked by leaf worm. As it turns out, after a few days the maggots will become a butterfly or beetle. So ... I chose to examine the development of the leaf worm.

Student 6 (KS): When I go to a clinic, I always see the pictures of cells, tissues, and organs of the human body, thus I know many form of cells, tissues, and organs. For this assignment, I will collect coloured pictures of cells, tissues and organ from the internet

In this project papers, students can be helped and guided by their own teachers. According to Crawford (2001), the best learning is learning through direct experience, where students do not only observe directly, but also directly involved in the activity and is responsible for the results obtained. Bouillion and Gomez (2001) found that reality-based learning will be beneficial because teachers, students and partner organization work together. By involving students in doing learning activities will make them proficient in finding and revealing an interesting experience acquired during their life. Activities involving students can also stimulate self-confidence attitude where they can boldly explain the findings obtained. This shows that students are able to come up with theories to relate with their daily life practice.

Contextual strategy modules produced in this study include exercises involving the transfer of thinking skills into the students' daily life (Sternberg 1987). Activities carried out give the opportunity to students to develop their cognitive and metacognitive skills (Paul 1993). The exercise conducted also encourage students to express their thoughts orally or in writing reflectively. The conducted contextual strategies also provide opportunities for students to make a written response in the "Observation Report" in the form of paper work. This continuously occur until the students can finally practice more cognitive and metacognitive strategies (McCombs, 1998).

Slavin (1991) states that knowledge gained through self-discovery will be more meaningful than those obtained through lectures or explanations of others, and are easily applied in new situations. Based on these results it can be inferred that the RANGKA contextual strategy can improve the students' concept mastery. Through contextual learning, students will be actively involved and able to undergo meaningful experiences through real objects that they obtained from their own environment.

According to Johnson (2002), in order to help students develop their intellectual potential, contextual learning teaches the cognitive processes that can be used in critical and creative thinking as well as provide opportunities to use high level thinking skills in real life situations. In other words, science teaching and learning strategies practiced not only emphasizes the intellectual aspect alone but also the creative process and high thinking in the form of various learning strategies that should be created by teachers creatively.

Contextual learning approach will help students to discover by themselves, develop an understanding from new experiences that are integrated with early experience (constructivism). As noted by Lynn and Brandt (1997), learning approach are based on how a person learns. Strictly speaking, an interesting learning environment will make students more enthusiast to learn. According to Gardner (1995), basically students are intelligent genetically. But genetic factors alone are not enough for a person to develop his intellect. Hence the role of teachers and environment is far more important to make them successful to process and produce information. As for that, teachers need to train multiple intelligences, by asking analytical questions, solving problems logically, or plan an experiment to prove something.

Through contextual learning strategy, students are provided with high level thinking ability through the process of problem identification and analysis and learning activities that make learning more effective. With 
respect to this research, in identifying the characteristics of living things using cockroach (Periplaneta sp.), the following questions can be proposed:

a. What are the causes of Periplaneta sp. moving away from the light?

b. How Periplaneta sp. use oxygen?

c. Where Periplaneta sp. get oxygen?

d. When does Periplaneta sp. moving towards a darker place?

e. Who can explain how the breathing process of Periplaneta sp.?

f. Why after 10 minutes in a closed tube Periplaneta sp. drowned?

Therefore, this contextual module promotes higher thinking level, enhance active learning, enhance understanding and increase motivation. In addition, it creates a positive social environment for learning and help students to apply their knowledge in various situations.

The findings of the qualitative observations showed that students in the control group who were exposed to conventional teaching are less effective in the construction of formal thinking in a systematic and consistent manner. Almost all the time the teachers are found in delivering content in lecture approach. Teachers are still dominant and students are the passive recipients where they are fed with the correct answers when failed to solve problem on their own. Notes and scientific facts that need to be memorized in the examination are presented to students. Furthermore, time is minimal for the construction of a two-way social interaction between teachers and students.

Teachers need to have in depth knowledge on variety of teaching strategies because they serve as mentor in the classroom. Therefore, an ongoing teacher professional development need to be systematically designed and implemented. Training curriculum should be directed on four competencies which are professional competencies, pedagogical knowledge, personality, and social competencies (Depdiknas, 2008). Teacher training is important because of its role to develop the skills and confidence in applying a variety of teaching strategies. Lesson study strategy should also be promoted among teachers where teachers cooperate among themselves to observe and comment upon their teaching styles.

Teacher training also serves to develop skills to evaluate the implementation of student-centered learning by applying various teaching and evaluating strategies. Activities on students' worksheet with the blending of process skills and problem solving can be used by teachers as an evaluation tool to measure psychomotor and scientific attitude.

The implementation of Education Curriculum in Indonesia in 2013 is an improvement from the Competency Based Education Curriculum in 2006. The 2013 curriculum emphasizes direct experience catering to the expansion of scientific process skills and attitude in order for students to understand science concepts and thinking skills through problem solving activities. The learning activities are concentrated towards students' knowledge and skill development process. Besides, character development and spiritual values are integrated in all subjects (Depdiknas, 2013).

Changes in the curriculum should be accompanied by changes in ways of thinking. This is in accordance to what had been proposed by Costa and O'Leary, (1992) that states changing curriculum means changing your mind. Mindset change should not only be applied to teachers in school, but also by all elements related to education. Such changes in science teachers' mindset is crucially important in ensuring that science teachers are always ready and competent in delivering the teaching and learning approaches as stipulated in the curriculum.

In the context of this study, through the phase of problem summary, merge, and practice in the RANGKA will establish a better scientific attitude, particularly curiosity, responsibility and cooperation. Several alternatives can be used to grab the students' attention and increase students' scientific attitude by using different teaching aids and challenging tasks and activities that are foreign to them. Pedrotti (1997) also highlighted the context of sharing and communicating with each other as an important teaching element. In doing so, teachers need to play a vital role in promoting good collaborative attitude in teaching and furtherly making teaching as an active process by varying student-centered activities.

Contextual learning strategies in this study provides implications towards curriculum practice where teachers must have the skills to plan the learning topic to achieve learning outcomes as specified in the syllabus. This means that teachers need to plan effective learning by paying attention to the availability of time, facilities and infrastructure, as well as the characteristics of the students. Additionally, contextual learning strategies will require teachers to act as mentors or facilitators in guiding students to become more intelligent, creative, innovative and respectful human being.

Contextual learning strategies not only help students in improving their conceptual mastery, but also improving their process skills, problem solving and scientific attitude. This research findings do provide direct implications on the implementation of science education in Indonesia, particularly in the Lower Secondary School. In a broader view, these findings also have implications in improving the quality of learning through learning innovation by 
providing good learning module. Furthermore, this study has implications in an effort to increase thinking skills, innovative learning strategies, teachers' training and system evaluation.

This study has shown that activities in contextual learning strategy will encourage critical thinking skills. RANGKA contextual strategies help students in the process of building networks and organizing the concepts in their cognitive domain and also develop high level thinking skills. Moreover, this research findings have implications on the enhancement of critical thinking skills, such as analysis, synthesis, and evaluation among students with various capabilities and different school categories. This strategy hinges on the development of high intellectual ability, where students progress from conceptual understanding level to much higher level of thinking skills which are the level of analysis, synthesis, and evaluation. Learning process emphasis on the process skills and problem-solving skills so that students are able to raise their critical thinking ability. By integrating science process skills in contextual learning, students will be more comfortable in implementing problem solving and will be able to transfer what is gained to a variety of situations.

This learning strategy will not be a success if there are no continuous improvement efforts made by teachers. For novice teachers generally, contextual learning approach can be used as an alternative of student-centered learning strategies. It is also suggested that teachers can implement the innovations and improvise it through class action research. Action research undertaken could be a stimulator to learning innovation that will impact the overall improvement of teaching and learning quality. These changes and innovations must be shared and understood by all teachers. It is expected that teachers will be able to apply the strategy within the context of current teaching and learning approaches as well as assessment practice.

Students who have the opportunity to be immersed in the contextual learning experiences will be able to use a variety of cognitive strategies in relating new information with their existing knowledge. Students will strive to execute activities that are stimulating and challenging. Whereas their peers in the control group who did not perform contextual strategies are found to merely memorize facts and are less exposed to the process and problemsolving skills. This is because reasoning capabilities are essential to enhance the abstract science concept understanding.

This study has also revealed that active student-centered learning will boost the interest and foster healthy and positive social interaction towards achieving learning goals as well as enhance critical thinking skills among students. Group activities and group assessment will increase the creative thinking process. Contextual module in the form of lesson plans, student books, work sheets, and variety of assessment instruments pose implications for the direction of teacher professional development. Teachers should have a deep understanding on the content knowledge and skillful in practicing various learning strategies. In conjunction, teachers' self-confidence will be enhanced as the learning progress made by students. Science teachers as key players will successfully meet the challenges if they have the appropriate academic qualifications and always constantly strive to expand their potential and skills.

\section{SUMMARY}

Research on contextual learning should be developed continously. RANGKA contextual learning strategies can be used as an alternative strategy in the Active, Innovative, Creative, Effective and Fun or also known as Pembelajaran Aktif Inovatif Kreatif Efektif dan Menyenangkan (PAIKEM) in various different school categories. Contextual learning modules as developed in this study could be used as a reference in the development of lesson plans, especially for novice teachers who teach at Lower Secondary School. RANGKA strategies are not only limited to the topic used in this study, but it has the potential to be expanded on other topics in science learning. RANGKA strategy is a student-centered learning, with emphasis on learning activities that encourage students to think critically and creatively as part of the life skills students should possess. However, this study only contributes to a small part of the science learning innovation. Effect of RANGKA strategy can be further extended in different teaching and learning situations and circumstances by science education researchers.

\section{ACKNOWLEDGEMENTS}

Support for this project was funded by Ministry of Research, Technology and Higher Education. The ideas in this manuscript are solely generated by the authors. We would like to thank to everyone who has directly and indirectly involved towards successful implementation of this study. 


\section{REFERENCES}

AAAS. (1993). Benchmarks for Scientific Literacy. New York: Oxford University Press.

Anderson, L. W. (1980). Assessing Affective E Characteristic in the Schools. Boston: Allyn and Bacon

Anderson, L. W., \& Krathwohl, D. R. (2001). A Taxonomy for Learning, Teaching and Assessing, A Revision of Bloom's Taxonomy of Educational Objectives. NewYork: Addison Wesley Longman, Inc.

Beyer, B. K. (1988). Helping children think better. The development lesson set approach. Journal of Research and Development in Education, 26(2), 97 - 105.

Blank, E., \& Harwell, S. H. (2001). Promising Practices. Waco, Texas: CCI Publishing.

Blumenfeld, P. C., Soloway, E., Marx, R. W., Krajcik, J. S., Guzdial, M., \& Palincsar, A. (1991). Motivating ProjectBased Learning: Sustaining the doing, supporting the learning. Educational Psychologist, 26(3\&4), 369-398.

Bouillion, L. M., \& Gomez, L. M. (2001). Connecting school and community with science learning: real world problems and school-community partnerships as contextual scaffolds. Journal of research in science teaching, 38(8), 878-898.

Bricheno, P., Johnson, J., \& Sears, J. (2000). Children's attitudes to science: beyond the men in white coats. In issues in science teaching. Routledge: London.

Bruner, J. (1977). The Process of Education: A landmark in educational Theory. Harvard: University Press.

Carin A. A. (1993). Teaching Modern Science. $6^{\text {th }}$ Ed. New York: Macmillan Publishing Company.

Carin, A. A., \& Bass, J. E. (2001). Teaching Science as Inquiry. 9th Ed. New Jersey: Merril Prentice- Hall Inc.

Chiappetta, E. L., \& Koballa, T. R. (2002). Science Instruction in the Middle and Secondary Schools. 2nd Ed. New Jersey: Merril.

Chu, H. C. (2014). Potential negative effects of mobile learning on students' learning achievement and cognitive load - A Format assessment perspective. Educational Technology \& Society, 17(1), 332-344.

Costa, A. L., \& O'Leary, P. W. (1992). Co-cognition: The cooperative development of the intellect. Enhancing thinking through cooperative learning, 41-65.

Crawford, M. L. (2001). Teaching contextually: Research, rationale, and techniques for improving student motivation and achievement in Mathematics and Science. Texas: CORD

Creswell, J. W. (2002). Educational research: Planning, conducting and evaluating quantitative and qualitative research. Upper Saddler River, New Jersey: Merril Prentice Hall.

Daniels, H., \& Bizar M. (1998). Methods that matter: Six structures for best practice classrooms. Maine: Stenhouse.

Depdiknas. (2005). Standard Kompetensi Mata Pelajaran Sains SMP. Jakarta: Pusat Kurikulum,Balitbang Depdiknas.

Depdiknas. (2008). Model Penyelenggaraan Sekolah Kategori Mandiri /Sekolah Standar Nasional. Jakarta: Direktorat Jenderal Manajemen Pendidikan Dasar dan Menengah.

Depdiknas. (2013). Standar Kompetensi Mata Pelajaran IPA SMP. Jakarta: Direktorat Jenderal Pendidikan Dasar dan Menengah.

Deshler, D. D., \& Schumaker, J. B. (1994). Strategy mastery by at-risk students: Not a simple matter. The Elementary School Journal, 94(2), 153-156.

Dick, W., Carey, L., \& Carey, J. O. (2005). The Systematic Design of Instruction. 6th ed. Boston: Pearson.

Gagne, R. M., Wager, W. W., Golas, K. C., \& Keller, J. M. (2005). Principles of Instructional Design. 5 ${ }^{\text {th }}$ edition, Singapore: Wadsworth Thomson Learning Inc.

Gall, J. P., Gall, M. D., \& Borg, W. R. (2005). Applying Educational Research: A practical Guide. 5th. ed. Boston: Pearson Education, Inc.

Gardner, P. L. (1995). Measuring attitudes to science: Unidimensionality and internal consistency revisited. Research in science education, 25(3), 283-289.

Harlen, W. (1996). Teaching and Learning Primary Science. London: Paul Chapman Publishing.

Harwell, S. H. (1999). Why do I have to learn this? Workbook. Texas: CORD.

Hull, D., \& Greveelk, J. H. (1998). Technical preparation: The Next Generation. Waco Texas: Center Occupational Research and Development.

Hung, D. W., \& Wong, A. F. L. (2000). Activity Theory as a Framework for Project Work in Learning Environments. Educational Technology, 40(2), 33-37.

Hunkins, F. P., \& Shapiro, P. (1967). Teaching critical thinking in elementary social studies. London: Macmillan Company. 
Johnson, E. B. (2002). Contextual Teaching and Learning: What it is and why it's here to stay. California: Corwin Press, Inc.

Kamisah, O., Zanaton, H. I., \& Lilia, H. (2007). Sikap terhadap sains dan sikap saintifik di kalangan pelajar sains. Jurnal Pendidikan, 32(3) 39-60.

Kemp, J. E., Morisson, G. R., \& Steven, M. R. (1994). Designing Effective Instruction. New York: MacMillan College Publishing Company.

Kenyon, L. O. (2003). The effect of explicit, inquiry instruction on freshman college science majors' understanding of the nature of science (Unpublished doctoral dissertation). University of Houston.

Lynn, M. J., \& Brandt, R. S. (1997). The Language of Learning: A Guide to Education Terms. Alexandria: Association for Supervision and Curriculum Development.

Main, J. D., \& Rowe, M. D. (1993). The relation of locus of control orientation and task structure to problem solving performance of sixth-grade student pairs, Journal of Research in Science Teaching, 30(4), 401-426.

Martin, R., Sexton, C., \& Gerlovich, J. (2002). Teaching Science for All Children: Methods for constructing understanding. Boston: Allyn and Bacon.

Marzano, R. J. (1992). A Different Kind of Classroom: Teaching with Dimensions of Learning. Virginia: ASCD.

McCombs, B. L. (1998). Integrating metacognition, affect, and motivation in improving teacher education, 379 - 408.

Muhfahroyin, M. (2009). Memperdayakan kemampuan berfkir kritis siswa melalui pembelajaran konstruktivisme. Jurnal pendidikan dan pembelajaran. 16(1).

Nitko, A. J. (2004). Educational assessment of Students. $4^{\text {th }}$ Ed. Upper Saddle River, NJ: Merril

Oates, K. K. (2002). Inquiry Science: Case Study in Antibiotic Prospecting. The American Biology Teacher, 64(3), 184187.

Oliva, P. (2004). Developing the Curriculum. $6^{\text {th }}$ Ed. Boston: Pearson.

Pallant, J. (2001). SPSS Survival. A step-by step guide to data analysis using SPSS for Window (version 10). New South Wales, Australia: Allen \& Unwin.

Parnell, D. (2001). Contextual Teaching Works. Waco Texas: Center for Occupational Research and Development.

Paul, R. W. (1993). Critical Thinking: How to Prepare Students for a Rapidly Changing World. Santa Rosa, CA: Foundation for Critical Thinking.

Pedrotti, L. S. (1997). An effective System of Education for Many Secondary and Postsecondary Students. Center for Occupational Research and Development, Waco, Texas.

Philips, J. (1996). Developing critical and creative thinking in children. Selangor: Lingua Publications.

Piaget, J. (1966). Psychology of Intelligence. Totowa New York: Littlefield and Adams.

Pintrich, P. R., \& Schunk, D. H. (1996). Motivation in Education: Theory, Research, and Application. New Jersey: Prentice Hall.

Richmond, G., \& Striley, J. (1996). Making Meaning in Classrooms: Social Processes in small-Group Discourse and Scientific Knowledge Building. Journal of Research in Science Teaching, 33(8), 839-858.

Rowntree, D. (1990). Teaching through self-instruction: How to develop open learning materials (Revised edition). Pentonville Road, London: Kogan Page, Ltd.

Rustaman, N. Y. (2008). Teaching Science to develop scientific abilities in Science Education. Proceeding of the $2^{\text {nd }}$ International Seminar of Science Education, 94-99.

Schlechty, P. C. (1997). Inventing better schools an action plan for educational reform. New York: Jossey-Bass.

Shayer, M., \& Adey, P. (1981). Towards a Science of Science Teaching. London: Heineman Educational.

Slavin, R. E. (1991). Educational Psychology: Theory into Practice. Englewoods Cliff, New Jersey: Prentice Hall.

Sternberg, R. J. (1987). Teaching Critical Thinking: Eight ways to fail before you begin. Phi Delta Kappan, 68(6), 456459.

Thiagarajan, S., Semmel, D. S., \& Semmel. M. I. (1974). Instructional Development for training Teachers of Exceptional Children. Source book. Bloomingtoon: Center for Innovation on Teaching the Handicapped.

Triyanto. (2010). Pengantar Penelitian Pendidikan bagi Pengembangan Profesi Pendidikan dan Tenaga Kependidikan, Jakarta, Kharisma Putra Utama

Tuckman, B. W. (1999). Conducting Educational Research, 5th ed. New York: Harcourt Brace College Publishers.

Von Glasserfeld, E. (1992). Cognition, construction of knowledge and teaching system. Journal of Research in Science Teaching. 80,121-140. 
Vygotsky, L. S. (1978). Mind in society: The development of higher psychological processes. Cambridge, Mass: Harvard University Press.

Wolfensberger, B., Piniel, J., Canella, C., \& Kyburz-Graber, R. (2010). The Challenge of involvement in reflective teaching: Three case studies from a teacher education project on conducting classroom discussions on socioscientific issues. Teaching and Teacher Education, 26(3), 714-721.

Zemelman, S., Daniel, H., \& Hyde, A. (1998). Best Practice: New Standards for teaching and learning in America's School. 2nd Ed. New Hampshire: Heinemann.

\section{http://www.ejmste.com}

